\title{
A Survey of Care And Support for the Elderly People in Nigria
}

\author{
Dr A.D. Shofoyeke
}

National Institute for Educational Planning and Administration, Nigeria, P.M.B. 562, Ondo

Email: shofoyekeng@yahoo.com

Dr. P A Amosun

Department of Teacher Education, Faculty of Education, University of Ibadan, Nigeria

\section{Doi:10.5901/mjss.2014.v5n23p2553}

\section{Abstract}

\begin{abstract}
The study examined care and support for the elderly people in Nigeria. A questionnaire for assessing level of awareness of care and support, nature of occupation and challenges facing elderly people was developed, validated and reliability coefficient found to be 0.75 . The questionnaires were administered to 684 principals, head teachers, education administrators and planners in four out of six geo-political zones in Nigeria. A state was randomly selected from each geo-political zone for administration of the questionnaires. These states are Bayelsa, Imo, Kogi and Lagos for South-South, South-East, NorthCentral and South-West geo-political zones respectively. The quantitative data generated from the questionnaires were analysed using percentages and Chi-square statistics. The study found that overall, men were more aware of elderly persons living close to them than women did however there were variations in the four geo-political zones. There was no significant relationship between male and female knowledge of where elderly people live. Respondents indicated that elderly persons 225 live with their children, 154 live with extended family, 104 live alone, while 28 live in few missions and government elderly people's homes. Furthermore, elderly persons engaged in different occupation for living which the study found that 210 are self-employed, 177 care for children, 115 are employed by individuals, 77 engaged in politics while 42 said they beg for alms. The study also found that most elderly people have no access to portable water, decent accommodation and hence live in poor environment especially in the rural areas and urban slums. In addition, government at all levels have no clear welfare programme for the elderly people, no elderly age security, subsidized health services, adequate elderly age people home among others. Besides, children neglect them due to poverty caused by unemployment and underemployment and to some extent beliefs that elderly persons are withes and wizards. The paper recommends that governments at all levels should develop lasting and beneficial economic and welfare programmes for the elderly. Non- governmental organizations should also be encouraged to develop welfare, skill and economic programmes to aid elderly while good communual and customary family support practices be encouraged and sustained. Furthermore, policy on elderly people be enacted and implemented by all the stakehelderlyers.
\end{abstract}

Keywords: Survey, Care and Support, Elderly People, Geo-political zones

\section{Introduction}

There are no commonly used definitions of elderly age because there is no general agreement on the age at which a person becomes old. The common use of a calendar age to mark the threshold of old age assumes equivalence with biological age, yet at the same time, it is generally accepted that these two are not necessarily synonymous. However, most developed countries have accepted the chronological age of 65 years as a definition of 'elderly' or old person, but like many westernized concepts, this does not adapt well to the situation in Africa. The United Nations defines older persons as "those aged 60 years and above". In many African countries the UN definition appears inappropriate as formal retirement age from formal sector service range between 55 and 65 years (Helpage International, 2007). In Nigeria, the National Population Commission (2004) defines elderly persons as "those aged 65 years and above".

The International Anthropological study conducted by Glascock (1980) indicated that definition of old age in Africa can be categorized into three (1) chronology; (2) change in social role (i.e. change in work patterns, adult status of children and menopause); and (3) change in capabilities (i.e. invalid status, senility and change in physical characteristics). Results from this cultural analysis of old age suggested that change in social role is the predominant means of defining old age. These results somewhat contradict the findings of a later study conducted in Nigeria regarding perceptions about the onset of old age (Togonu-Bikersteth, 1987 and 1988). The results suggested that the generally 
accepted definition was similar to westernized definitions of old age; however, this was a unique community with culturerelated norms that bestowed certain privileges and benefits at old ages. If one considers the self-definition of old age, that is old people defining old age, as people enter older ages it seems their self-definitions of old age become decreasingly multifaceted and increasingly related to health status (Brubaker, 1975, Johnson, 1976 and Freund, 1997).

In rural situations, where birth registration is either is either poor or unknown, physical features are commonly used to estimate a person's age (UN, 1991cited by Helpage International, 2007). It states further that a person's hair, failing eye sight and diseases such as arthritis as well as social and cultural issues like person's seniority status within his/her community, the number of grandchildren which he/she has are some common features for defining old age. In Nigeria, the situation is not different from this description. A critical examination of some of these features may not be valid in actual term. For instance, early appearance of gray air could either be hereditary or occur as a result of stress while having grandchildren might be due to early marriage. If a person gives birth to a child at age fifteen, the child also gives birth at age sixteen, then by age thirty-one, that person is already a grandparent. This example is common in Africa and other developing nations particularly where literacy is low.

In terms of trend, about three decades ago, the global population was viewed as "young" rather than "elderly". 35 percent of all elderly persons in the world were 14 years of age or younger, compared to only 8.5 percent who were 60 and over (Link age, 2000). Since then, the world population aged 60 years and above has been increasing rapidly as shown by the following data. The figure increased from 200 million in 1950 to 350 million in 1975 representing about 75 percent, and by 1999 it had short up to nearly 600 million (US Bureau of the Census,1999). UNFPA (1999) states that this figure is at over 11 million a year and is projected that by 2025 it will reach 1.2 billion and 2 billion by 2050. In Nigeria, the increasing population growth occasioned by the in-built population momentum since the last 3 decades has impact for the population structure. The 1991 population census shows that 44 percent of the population are children under 15 years, while 3.3 percent are aged 65 years and above and about 3.7 percent of the rural population as against 2.5 percent of the urban fall within this cohort (National Population Commission, 2006). On the other hand, United Nations (2005) estimated that $5 \%$ of the total population was aged 60 and above which was expected to reach $6.0 \%$ in 2025 and $9.9 \%$ in 2050. This represents 6.4 million, 11.5 million and 25.25 million ageing people respectively and according to Mudiare (2013) Nigeria has the largest number of elderly people over 60 years of age, South of Sahara, yet there is very little put in place by the government as institutional policies and legislation. Wikipedia (2014) puts the proportion of elderly population age 65 and above as 3.23 per cent.

Evidences around the world show that ageing is associated with different diseases such as dementia, arthritis, heart disease and diabetes (UNFPA, 1999; Sammut, 2007). Traditionally, in Nigeria, the extended family system has cared for the Nigerian elderly. Okumagba (2011)found that the family still accounts for a large proportion of the support Thus, most aged persons expect support from their relatives, friends but most especially from their children. As a result of this, the need for elderly age security from children was one of the motivations for large family size in Nigeria. However, because of the declining economy, unemployment, underemployment, inflation among others, many children are no longer in a position to provide care and support for their aged parents and relatives while the family support networks are on decline. In the same token, urbanization has also broken down the traditional sense of family responsibility. In rural sub-Saharan African, urbanization often leads to young people being separated from their grandparents who previously played a special role in their traditional education and socialization of the young (UNFPA, 1999). Unlike the economically developed countries, lack of social security scheme worsens the predicaments of the elderly. According to Gesinde, Adekeye and Iruonagbe (2011) elderly people's lives in Nigeria are characterised by growing inadequacies in customary family supports, social exclusion and non-existent social security. Furthermore, the impact of HIVIAIDS epidemic is leading to rising mortality among working adults which suggests that young adults may die before their ageing parents in some cases, leaving the elderly with reduced support and additional responsibility of caring for orphans.

In rural settlements in Nigeria that are close to big towns and cities, plantations and agricultural lands are elderly off either by families or individuals for building housing estates, houses and construction of industries due to expansion and thereby leaving farmers who eke on the land with nothing as means of livelihood. The most unfortunate thing about this is that the affected are neither skilled in other professions nor educated enough to be absorbed in the new environment and worst still, governments do not always plan for such people. In effect, the practice leads to increasing number of poor ageing population, the aged are in want of survival while the active youths engage in menial jobs that can hardly sustain them. In Nigeria, the burden of care squarely rests on family members despite the provisions in the 1999 Constitution, Section 14.2(b) which states categorically that, "The security and welfare of its people shall be the primary purpose of the government" and in Section 16, sub-section 2(d) promises, "That suitable and adequate shelter and suitable and adequate food, reasonable national minimum living wage, elderly age care and pensions and unemployment, sick benefits and welfare of the disabled are provided for all citizens." In practice, the government seems 
to have reneged on these promises as most elderly are not covered by any social security scheme except some ad hoc programmes by Ekiti state and some local governments in which gift items are given to elderly but such are not sustainable. The pensioners in the formal employment have pension benefits which are inadequate and often delayed due to corruption in the pension system. While the growing concern for increasing number of elderly people around the globe and the need to provide care and support for them led the adoption of the International Plan of action on Ageing in Madrid in 2002 as well as development of other policy frameworks at the regional level such as: African Union Policy Framework and Plan of Action on Ageing (2003), National Policy on Care and Wellbeing of the Elderly Economic Committee for Africa - The State of Elderly People in Africa (Draft 2007), there is no such genuine concern in Nigeria even where the country is a signatory to international policy (Ajomale, 2007b).

There is dearth of studies on generotology and particularly care and support in Nigeria. Lack of welfare services, non-inclusion in national population policy as well as educational and economic programmes characterize the elderly population. This state of neglect has promoted some elderly poor to beg for alms at public functions, parks, take up odd jobs which are indicative in their appearances and utterances. Besides, preference is given to burial of the aged than care while alive. The aforementioned observations which were not common in the past informed this study.

\subsection{Statement of the Problem}

In view of our observed increasing alms begging at major streets, public motor parks and social functions by poor elderly people, this study was conceived with the intension of finding the level of care and support for the ageing population in four geo-political zones in Nigeria. Level of awareness of ageing persons living in respondents' community and nature of work done was included in the investigation.

\subsection{Significance of the Study}

Having increasing number of ageing population is an indicator of high survival rate occasioned by good health system and condition of living. At the family level, it is a pride in some communities in Nigeria to have their parents or relations ageing who are elders because of their roles in recounting past stories, customs, traditions and care for the children. On the other hand, they tend to become liabilities to the family when they pose health problems requiring fund for treatment or constitute total economic dependent on children and family. At the community or national level, elderly persons become liabilities when they are not contributing to the economy and much money has to be set aside for their health provision and other services. As a result of poverty at family level and government non-provision for the ageing, a significant number engaged in alms begging and other undignified practices to earn living. These practices were considered in the past as taboo. The study therefore investigated into the level of awareness of elderly people living in the respondents' area with a view to knowing the level of care and support available for them. The findings of this study provided information on the level of awareness of elderly persons living among the respondents and level of care and support. It further provided information for comparing the level of awareness, care and support between geo-political zones in the country, types of occupation engaged in, their challenges and means of addressing them. In addition, it provided useful basis upon which further studies can be made.

\section{Methodology}

The study adopted a survey research of the respondents in that the population under study is large. School principals, head teachers and school administrators were randomly sampled in four out of six geo-political zones in Nigeria. A total of 684 respondents were sampled across four geo-political zones in Nigeria, namely Lagos in South West, Imo in SouthEast, Bayelsa in South-South and Kogi in North-Central. This sample comprised 361 male and 323 female.

The respondents were chosen because they are literate, mature and are aware in their environment. Lagos state was selected from South West because it is a city that accommodates all tribes in Nigeria and Citizens of other countries and the data collected from this state could be representative of Nigeria to some extent. Bayelsa was selected from South-South due to the fact that it has rural, urban and riverine and inhabits mostly ljaws. Imo state was selected from south-east as result of the fact that it has both urban and rural as well as the most literate state in the geo-political zone which is predominantly inhabited by Igbos. In the same vein, Kogi state was selected from North Central in that it has both rural and urban, the inhabitants are Ibras, Yorubas and Igalas. These zones are culturally different and practices relating to care and support for the elderly could be compared.

Questionnaire on elderly population care and support was designed and validated by experts in gene otology and 
sociology. The validated instrument has two sections namely A and B. Section A contained biodata of the respondents which include gender, profession or occupation, location or town of residence. Section B contained information on the care and support for the elderly, type of work they do for living and the problems associated with such work, and major challenges facing the elderly persons. The validated questionnaire was trial tested on fifty comparable respondents. Data generated was computer analysed using Cronbach Coefficient Alpha in which 0.75 was obtained. This indicated that the test items are consistent in measuring what they supposed to measure. After this, the final instrument was administered to the respondents in different geo-political zones.

The data generated from the field work was analysed using descriptive statistics to compare the responses from the zones. Chi-square was used to determine the relationships between the observed care and support, challenges and expected.

\section{Results}

Research Question 1: Is there any significant relationship between male and female awareness of elderly people living in their environment?

Table 1: Respondents' knowledge of living and welfare services for the elderly people by gender.

\begin{tabular}{|c|c|c|c|c|c|c|c|c|c|}
\hline \multirow[t]{2}{*}{ Item (Overall) } & Responses & $\begin{array}{c}\text { Male } \\
(n=361) \\
\text { No } \\
\end{array}$ & $\%$ & $\begin{array}{c}\text { Female } \\
(n=323) \\
\text { No } \\
\end{array}$ & $\%$ & $\begin{array}{c}\text { Total } \\
(n=684) \\
\text { No }\end{array}$ & $\%$ & $\mathrm{X} 2$ & Sig, \\
\hline & No Response & 5 & 0.73 & 4 & 0.58 & 9 & 1.31 & \multirow{3}{*}{0.223} & \multirow{3}{*}{0.636} \\
\hline \multirow{2}{*}{ Area there aged people in your area? } & Yes & 353 & 51.61 & 315 & 46.05 & 668 & 97.66 & & \\
\hline & No & 3 & 0.44 & 4 & 0.58 & 7 & 1.02 & & \\
\hline \multirow{3}{*}{ South-South-Bayelsa } & No Response & 4 & 0.58 & - & - & 4 & 0.58 & \multirow{3}{*}{0.973} & \multirow{3}{*}{0.615} \\
\hline & Yes & 143 & 20.91 & 20 & 2.92 & 163 & 23.83 & & \\
\hline & No & 3 & 0.44 & - & - & 3 & 0.44 & & \\
\hline \multirow{3}{*}{ South-East: Imo } & Yes & 82 & 11.99 & 68 & 9.94 & 150 & 21.93 & \multirow{3}{*}{-} & \multirow{3}{*}{-} \\
\hline & No Response & 6 & 0.88 & 5 & 0.73 & 10 & 1.61 & & \\
\hline & No & 4 & 0.58 & 5 & 0.73 & 9 & 1.31 & & \\
\hline \multirow{2}{*}{ North Central: Kogi } & No Response & 1 & 0.15 & - & - & 1 & 0.15 & \multirow{2}{*}{0.677} & \multirow{2}{*}{0.411} \\
\hline & Yes & 103 & 15.06 & 70 & 10.23 & 173 & 25.29 & & \\
\hline \multirow{3}{*}{ South-West: Lagos } & No Response & - & - & 4 & 0.58 & 4 & 0.58 & \multirow{3}{*}{0.812} & \multirow{3}{*}{0.666} \\
\hline & Yes & 15 & 2.19 & 147 & 21.49 & 162 & 23.68 & & \\
\hline & No & - & - & 4 & 0.58 & 4 & 0.58 & & \\
\hline
\end{tabular}

Table 1 shows that overall $51.6 \%$ of the men were aware elderly people living in their area as against $46.1 \%$ of women. There was no significant relationship in their level of awareness $X^{2}(2, N=684)=.223 ; p=.636$. Samples from three of the four geo-political zones show the same trend. In South-South $20.91 \%$ of the men were aware of elderly people living in their area as against $2.92 \%$ of the women. However, no significant relationship existed between men and women awareness of elderly people living in their area $X^{2}(2, N=170)=.973 ; p=.615$. In south-east, $11.99 \%$ of men were aware as opposed to $9.94 \%$ of women. In North Central, $15.06 \%$ of men were aware of elderly people living in their area as against $9.94 \%$ of women but no significant difference existed in their level of awareness $X^{2}(1, N=174)=.677 ; p=.411$. In SouthWest, only $2.19 \%$ of men were aware of elderly people living in their area as opposed to $21.49 \%$ of women. No significant difference existed in their level of awareness $X^{2}(2, N=170)=.812 ; p=.666$. It could be observed that men are least aware of elderly people living in their area in South-West (Lagos) while women in South-South (Bayelsa) are least among women. 
Question 2: What is the pattern of elderly people mode of living?

Table 2: Knowledge of elderly people mode of living

\begin{tabular}{|c|c|c|c|c|c|c|c|c|c|}
\hline Item & Responses & $\begin{array}{c}\text { Male } \\
(n=361) \\
\text { No }\end{array}$ & $\%$ & $\begin{array}{c}\begin{array}{c}\text { Female } \\
(n=323) \\
\text { No }\end{array} \\
\end{array}$ & $\%$ & $\begin{array}{c}\text { Total } \\
(n=684) \\
\text { No }\end{array}$ & $\%$ & $X^{2}$ & Sig. \\
\hline Overall & No Response & 62 & 9.06 & 81 & 11.84 & 143 & 20.9 & \multirow{5}{*}{31.3} & \multirow{5}{*}{0} \\
\hline \multirow{4}{*}{ With whom do they live? } & Alone & 73 & 10.67 & 31 & 4.53 & 104 & 15.2 & & \\
\hline & Children & 114 & 16.67 & 141 & 20.61 & 255 & 37.28 & & \\
\hline & Extended family & 92 & 13.45 & 62 & 9.06 & 154 & 22.51 & & \\
\hline & Elsewhere & 20 & 2.92 & 8 & 1.17 & 28 & 4.09 & & \\
\hline Geo-Political zones) & No Response & 6 & 0.88 & 2 & 0.29 & 8 & 1.17 & \multirow{5}{*}{5.03} & \multirow{5}{*}{0.285} \\
\hline \multirow[t]{4}{*}{ South-south: Bayelsa } & Alone & 65 & 9.51 & 8 & 1.17 & 73 & 10.68 & & \\
\hline & Children & 50 & 7.31 & 9 & 1.32 & 59 & 8.63 & & \\
\hline & Extended family & 22 & 3.22 & - & - & 22 & 3.22 & & \\
\hline & Elsewhere & 7 & 1.02 & 1 & 0.15 & 8 & 1.17 & & \\
\hline \multirow{5}{*}{ South-East: Imo } & No Response & 41 & 5.99 & 19 & 2.78 & 60 & 8.77 & \multirow{5}{*}{18.7} & \multirow{5}{*}{0.001} \\
\hline & Alone & 2 & 0.29 & - & - & 2 & 0.29 & & \\
\hline & Children & 43 & 6.29 & 43 & 6.29 & 86 & 12.58 & & \\
\hline & Extended family & 2 & 0.29 & 14 & 2.05 & 16 & 2.34 & & \\
\hline & Elsewhere & 4 & 0.58 & 2 & 0.29 & 6 & 0.87 & & \\
\hline \multirow{5}{*}{ North Central-Kogi } & No Response & 6 & 0.88 & 5 & 0.73 & 11 & 1.61 & \multirow{5}{*}{4.31} & \multirow{5}{*}{0.365} \\
\hline & Alone & 6 & 0.88 & 3 & 0.44 & 9 & 1.32 & & \\
\hline & Children & 18 & 2.63 & 21 & 3.07 & 39 & 5.7 & & \\
\hline & Extended family & 65 & 9.5 & 36 & 5.26 & 101 & 14.76 & & \\
\hline & Elsewhere & 9 & 1.32 & 5 & 0.73 & 14 & 2.05 & & \\
\hline \multirow{4}{*}{ South-West-Lagos } & No Response & 9 & 1.32 & 55 & 8.04 & 60 & 9.36 & \multirow{4}{*}{8.31} & \multirow{4}{*}{0.04} \\
\hline & Alone & - & - & 20 & 2.92 & 20 & 2.92 & & \\
\hline & Children & 3 & 0.44 & 68 & 9.94 & 71 & 10.38 & & \\
\hline & Extended family & 3 & 0.44 & 12 & 1.75 & 15 & 2.19 & & \\
\hline
\end{tabular}

Table 2 shows the responses of pattern of living among the elderly people. Overall, the patterns of living of elderly people are with their children (37.28\%), extended family (22.51\%), alone (15.2\%) and elsewhere (senior citizen's home) (4.09\%). $10.67 \%$ male indicated that they live alone as against $4.53 \%$ of female. $16.67 \%$ of the male said they live with their children as against $20.6 \%$ female. $13.45 \%$ of male said they live with extended family while $9.06 \%$ female did. $2.92 \%$ male said they live elsewhere as against $1.17 \%$ female. There was significant relationship between male and female knowledge of the living pattern of elderly people $X^{2}(4, N=684)=31.317 ; p=.000$. Many elderly people live with their children, next with extended family, and then alone while living elsewhere (elderly people's home or mission) was least. In south-south, there was no significant relationship between male and female knowledge of pattern of living of elderly people $X^{2}(4, N=170)=5.025 ; p=.285$. However, living pattern shows that 73 live alone, 59 live with children, and 22 said they live with extended family while 8 live elsewhere.

In South-East, significant relationship existed between male and female knowledge of living pattern of elderly people $X^{2}(4, N=170)=18.707 ; p=.001 .86$ respondents said elderly people live with their children, 16 live with extended family, 6 live elsewhere (old peoples home) and 2 live alone.

In North-Central, there was no significant relationship between male and female knowledge of pattern of elderly people living. $X^{2}(4, N=170)=4.312 ; p=.365 .101$ respondents said elderly people live with extended family while 39 live with their children, 14 live elsewhere and 9 live alone.

In South-West, there was significant relationship between male and female knowledge of living pattern of elderly people $X^{2}(3, N=176)=8.314 ; p=.040 .71$ respondents said elderly people live with their children, 20 live alone and 45 live with extended family.

It can be further deduced from table 2 that in South-South, elderly people prefer living alone to living with their children, extended family and elsewhere like mission or elderly people's home respectively. In South-East, elderly people prefer mostly living with their children to extended family or elsewhere or alone. In North-Central, elderly people mostly 
prefer living with their extended family to their children or elsewhere or alone. On the other hand, in South-West, the preference of elderly people is living with their children to living alone or with extended family. Thus, it can be inferred that elderly people in South-East and South-West have common living pattern of highest preference for living with their children. On the other hand, highest living preferences among elderly in South-South and North-Central are living alone and living with extended family respectively.

Question 3: To what extent do elderly people live in urban and rural areas?

Table 3: Respondents knowledge of elderly people mode of living by location (urban and rural).

\begin{tabular}{|c|c|c|c|c|c|c|c|c|c|}
\hline Zones & Responses & $\begin{array}{c}\text { Urban } \\
\text { No }\end{array}$ & $\%$ & $\begin{array}{c}\text { Rural } \\
\text { No }\end{array}$ & $\%$ & $\begin{array}{c}\text { Total } \\
\text { No }\end{array}$ & $\%$ & $\mathrm{X}^{2}$ & Sig. \\
\hline \multirow{5}{*}{ Overall } & No Response & 137 & 20.03 & 6 & 0.88 & 143 & 20.91 & \multirow{5}{*}{9.87} & \multirow{5}{*}{0.002} \\
\hline & Alone & 98 & 14.33 & 6 & 0.88 & 104 & 15.21 & & \\
\hline & Children & 254 & 37.13 & 1 & 0.15 & 255 & 37.28 & & \\
\hline & Extended family & 153 & 22.37 & 1 & 0.15 & 154 & 22.52 & & \\
\hline & Elsewhere & 28 & 4.09 & - & - & 28 & 4.09 & & \\
\hline \multirow{5}{*}{ South-south: Bayelsa } & No Response & 6 & 1.32 & 2 & 0.29 & 8 & 57.29 & \multirow{5}{*}{1.07} & \multirow{5}{*}{0.302} \\
\hline & Alone & 69 & 10.09 & 4 & 0.58 & 73 & 10.67 & & \\
\hline & Children & 59 & 8.63 & - & - & 59 & 8.63 & & \\
\hline & Extended family & 21 & 3.07 & 1 & 0.15 & 22 & 3.22 & & \\
\hline & Elsewhere & 8 & 1.17 & - & - & 8 & 1.17 & & \\
\hline \multirow{5}{*}{ South-East: Imo } & No Response & 60 & 8.77 & - & - & 60 & 8.77 & \multirow{5}{*}{9.31} & \multirow{5}{*}{0.002} \\
\hline & Alone & 2 & 0.29 & - & - & 2 & 0.29 & & \\
\hline & Children & 86 & 12.57 & - & - & 86 & 12.57 & & \\
\hline & Extended family & 16 & 2.34 & - & - & 16 & 2.34 & & \\
\hline & Elsewhere & 6 & 1.32 & - & - & 6 & 1.32 & & \\
\hline \multirow{5}{*}{ North-Central: Kogi } & No Response & 7 & 1.02 & 4 & 0.58 & 11 & 1.6 & \multirow{5}{*}{1.1} & \multirow{5}{*}{0.294} \\
\hline & Alone & 7 & 1.02 & 3 & 0.44 & 9 & 1.46 & & \\
\hline & Children & 38 & 5.56 & 2 & 0.29 & 39 & 5.85 & & \\
\hline & Extended family & 101 & 14.77 & - & - & 101 & 14.77 & & \\
\hline & Elsewhere & 14 & 2.05 & - & - & 14 & 2.05 & & \\
\hline \multirow{4}{*}{ South-West: Lagos } & No Response & 64 & 9.36 & - & - & 64 & 9.36 & \multirow{4}{*}{0.71} & \multirow{4}{*}{0.401} \\
\hline & Alone & 20 & 2.92 & - & - & 20 & 2.92 & & \\
\hline & Children & 71 & 10.38 & - & - & 71 & 10.38 & & \\
\hline & Extended family & 15 & 2.19 & - & - & 15 & 2.19 & & \\
\hline
\end{tabular}

Overall, a significant relationship exists between urban and rural respondents on knowledge of where elderly people live $X^{2}(1, N=684)=9.871 ; p=.002$. Table 3 shows that no significant relationship exists between urban and rural respondents on where elderly people live in south-south, North-Central and south-west except South-East zone. Thus, at each level of pattern of living, elderly people live more in urban than rural areas. 
Question 4: Is there any significant difference between the respondents' knowledge of what the elderly people do for a living?

Table 4: Respondents' knowledge of what elderly people do for living.

\begin{tabular}{|c|c|c|c|c|c|c|c|c|c|}
\hline \multirow{2}{*}{\begin{tabular}{|l|} 
Item \\
(Zone) \\
\end{tabular}} & \multirow[b]{3}{*}{ Responses } & \multirow{3}{*}{$\begin{array}{c}\text { Male } \\
(n=361) \\
\text { No }\end{array}$} & \multirow[b]{3}{*}{$\%$} & \multirow{3}{*}{$\begin{array}{c}\text { Female } \\
(n=323) \\
\text { No }\end{array}$} & \multirow[b]{3}{*}{$\%$} & \multirow{3}{*}{$\begin{array}{c}\text { Total } \\
(n=684) \\
\text { No }\end{array}$} & \multirow[b]{3}{*}{$\%$} & \multirow[b]{3}{*}{$\mathrm{X}^{2}$} & \multirow[b]{3}{*}{ Sig, } \\
\hline & & & & & & & & & \\
\hline \multirow{7}{*}{ South-south: Bayelsa } & & & & & & & & & \\
\hline & No Response & 15 & 2.19 & - & - & 15 & 2.19 & \multirow{6}{*}{5.03} & \multirow{6}{*}{0.29} \\
\hline & Self-employed & 43 & 6.29 & 7 & 1.02 & 50 & 7.31 & & \\
\hline & Employed by individuals & 26 & 3.8 & 1 & 0.15 & 27 & 3.95 & & \\
\hline & Care for grandchildren & 38 & 5.56 & 8 & 1.17 & 46 & 6.73 & & \\
\hline & Engage in politics & 18 & 2.63 & 4 & 0.58 & 22 & 3.21 & & \\
\hline & Alms begging & 10 & 1.46 & - & - & 10 & 1.46 & & \\
\hline \multirow{6}{*}{ South-East } & No Response & 9 & 1.32 & 9 & 1.32 & 18 & 2.64 & \multirow{6}{*}{18.7} & \multirow{6}{*}{0.001} \\
\hline & Self-employed & 27 & 3.95 & 28 & 4.09 & 55 & 8.04 & & \\
\hline & Employed by individuals & 13 & 1.9 & 15 & 2.19 & 27 & 4.09 & & \\
\hline & Care for grandchildren & 27 & 3.95 & 18 & 2.63 & 45 & 6.58 & & \\
\hline & Engage in politics & 12 & 1.75 & 4 & 0.58 & 16 & 2.33 & & \\
\hline & Alms begging & 5 & 0.73 & 4 & 0.58 & 9 & 1.31 & & \\
\hline \multirow{6}{*}{ North-Central: Kogi } & No Response & 9 & 1.32 & 9 & 1.32 & 18 & 2.64 & \multirow{6}{*}{4.31} & \multirow{6}{*}{0.37} \\
\hline & Self-employed & 31 & 4.53 & 21 & 3.07 & 52 & 4.54 & & \\
\hline & Employed by individuals & 22 & 3.22 & 9 & 1.32 & 31 & 5.26 & & \\
\hline & Care for grandchildren & 26 & 3.8 & 18 & 2.63 & 44 & 6.43 & & \\
\hline & Engage in politics & 10 & 1.46 & 7 & 1.02 & 17 & 2.48 & & \\
\hline & Alms begging & 6 & 0.88 & 6 & 0.88 & 12 & 1.76 & & \\
\hline \multirow{6}{*}{ South-West: Lagos } & No Response & 1 & 0.15 & 11 & 1.61 & 12 & 1.76 & \multirow{6}{*}{8.31} & \multirow{6}{*}{0.04} \\
\hline & Self-employed & 5 & 0.73 & 48 & \begin{tabular}{|l|}
7.02 \\
\end{tabular} & 53 & 7.75 & & \\
\hline & Employed by individuals & 2 & 0.29 & 28 & 4.09 & 30 & 4.38 & & \\
\hline & Care for grandchildren & 6 & 0.88 & 36 & 5.26 & 42 & 6.14 & & \\
\hline & Engage in politics & - & - & 22 & 3.22 & 22 & 3.22 & & \\
\hline & Alms begging & 1 & 0.15 & 10 & 1.46 & 11 & 1.61 & & \\
\hline
\end{tabular}

A breakdown of what the elderly do for living are as shown in table 4 which indicates that $X 2(5, N=684)=5.03: p=0.29$

* There is no significant relationship between respondents gender and knowledge of what elderly people do for living in south-south zone. Respondents indicated that elderly people are self-employed (7.31\%), employed by private individuals (3.95\%), care for grand-children (6.73\%); engage in politics (3.21\%) as well as alms begging (1.46\%). Most people are self-employed, followed by those caring for their grand-children, next by those employed by individuals, some engage in politics while the least number engage in alms begging.

* In South-East, there is a significant relationship between gender and their knowledge of what elderly people do for living (X2=18.707; $p<.001, d f=4)$. In this zone, elderly people engage in self-employment most (8.04\%), while other employments are in the following order: caring for grand-children (6.58\%), employed by individuals (either a security-men, gatemen, in case of males and as cleaners in case of women, 4.09\%), engage in politics (2.33\%) and alms begging (1.31\%).

* In North-Central zone, there is no significant relationship between gender and knowledge of what elderly people do for living. $(X 2=4.31, p=0.37, \mathrm{df}=4)$. Men differ significantly from women in their knowledge of what elderly people do in their area. Just as the other two zones, elderly people care for grand-children (6.43\%), seek employment by individuals (5.26\%), or are self-employed (4.54\%), engage in politics (2.48\%) and alms begging (1.76\%).

* In South-West zone, there is a significant relationship between respondents gender and their knowledge of what elderly people do for living in their area $(X 2=8.314 ; p=.042, d f=3)$. Same pattern of job was observed as others i.e. selfemployment, caring for grand-children, employed by individuals, engagement in politics and alms begging.

The study found that across all the zones, 210 are self-employed (7.75\%), 177 care for grand-children (6.14\%), 115 are employed by individuals (4.38\%), 77 engage in politics (3.22\%) and 42 beg for alms (1.61\%). 
The findings indicate that elderly people in Nigeria have unique way of living. However, one thing that strikes the researchers is alms begging that cuts across all the zones sampled. Why should elderly be begging for alms at motor garages, streets and parks to earn living in spite of how well-endowed the country is? This leads to the next research question on welfare.

Research Question 5: Do you have knowledge of welfare services and programmes put in place for the elderly people?

Table 5: Knowledge of Welfare services and programmes for the Elderly People

\begin{tabular}{|c|c|c|c|c|c|c|c|c|c|}
\hline Item (Zone) & Responses & $\begin{array}{c}\text { Male } \\
(n=361) \\
\text { No }\end{array}$ & $\%$ & $\begin{array}{c}\text { Female } \\
(n=323) \\
\text { No }\end{array}$ & $\%$ & $\begin{array}{c}\text { Total } \\
(n=684) \\
\text { No }\end{array}$ & $\%$ & $\mathrm{X}^{2}$ & Sig, \\
\hline \multirow{3}{*}{ South-south: Bayelsa } & No Response & 5 & 0.73 & 1 & 0.15 & 6 & 0.88 & \multirow{3}{*}{1.09} & \multirow{3}{*}{0.58} \\
\hline & Yes & 7 & 1.02 & - & - & 7 & 1.02 & & \\
\hline & No & 138 & 20.18 & 19 & 2.78 & 157 & 22.96 & & \\
\hline \multirow{3}{*}{ South-East: Imo } & No Response & - & - & 2 & 0.29 & 2 & 0.29 & \multirow{3}{*}{2.69} & \multirow{3}{*}{0.26} \\
\hline & Yes & 14 & 2.05 & 14 & 2.05 & 28 & 4.1 & & \\
\hline & No & 78 & 11.4 & 62 & 9.06 & 140 & 20.46 & & \\
\hline \multirow{4}{*}{ North-Central: Kogi } & No & 9 & 1.32 & 2 & 0.29 & 11 & 1.61 & \multirow{4}{*}{5.3} & \multirow{4}{*}{0.071} \\
\hline & Response & 21 & 3.07 & 8 & 1.17 & 29 & 4.24 & & \\
\hline & Yes & 74 & 10.82 & 60 & 8.77 & 134 & 19.59 & & \\
\hline & No & & & & & & 0 & & \\
\hline \multirow{3}{*}{ South-West: Lagos } & No Response & - & - & 13 & 1.9 & 13 & 1.9 & \multirow{3}{*}{5.75} & \multirow{3}{*}{0.057} \\
\hline & Yes & - & - & 31 & 4.53 & 21 & 4.53 & & \\
\hline & No & 15 & \begin{tabular}{|l|}
2.19 \\
\end{tabular} & 111 & 16.23 & 126 & 18.42 & & \\
\hline
\end{tabular}

Table 5 shows no significant relationship between gender and knowledge of welfare services and programmes available for the elderly people in each of the four geo-political zones sampled. In South-South only 7 men were aware of any welfare services or programmes for elderly people. In South-East, 14 men and 14 women were aware, 21 men and 8 women in North-Central and 31 women in South-West.

The level of knowledge of availability of welfare services and programmes for the elderly are 1.025\%, 4.1\%, 4.24\% and $4.53 \%$ respectively for South-South, South-East, North central and South-West. Overall, availability of social services and programmes are low across the geo-political zones but awareness of their existence is better in South-West, NorthCentral, South -East than South-South.

Table 6: Summary of Responses on Types of Social Services available and Challenges facing Elderly People

\begin{tabular}{|l|c|}
\hline Types of Welfare Programme & Frequency \\
\hline Poverty alleviation & 89 \\
\hline Free Medical Services & 64 \\
\hline Elderly people home & 46 \\
\hline Survivor Support & 10 \\
\hline Food security & 5 \\
\hline Recreational services & 6 \\
\hline Policy on elderly age & 6 \\
\hline Financial security & 6 \\
\hline Quality of living of elderly people & \\
\hline Not satisfactory & 176 \\
\hline Low standard of living & 243 \\
\hline Low quality & 143 \\
\hline Types of risks associated with elderly people & \\
\hline Sickness & 179 \\
\hline Hard labour & 144 \\
\hline Hunger and Diseases & 98 \\
\hline Drug Abuse & 56 \\
\hline Sickness and Death & 67 \\
\hline
\end{tabular}




\begin{tabular}{|l|c|}
\hline Frustration & 41 \\
\hline High blood pressure & 21 \\
\hline Challenges faced by elderly people & 446 \\
\hline No access to portable water & 68 \\
\hline Shortage of decent accommodation & 35 \\
\hline Poor environment & 20 \\
\hline Lack of care from children & 9 \\
\hline Poor feeding & \\
\hline Factors responsible for the challenges & 23 \\
\hline Improper planning & 46 \\
\hline Negligence by the elderly & 148 \\
\hline No assistance from work place, community and children & 118 \\
\hline Fear of elderly people associated with witchcraft & 29 \\
\hline Government outright neglect of elderly people & \\
\hline
\end{tabular}

Table 6 shows that welfare and public programmes available for elderly people identified by respondents are poverty alleviation 89 , free medical services 64 , elderly people home 46 , survivour support 10 , food security 5 , recreational services 5 , policy formulation 6 and financial security 2 . With little or no financial security/fund for the elderly coupled with no clearly stated policy for the elderly welfare indicate that governments in Nigeria have no respect for elderly age as opposed to economically developed countries that have elderly age people home as well as welfare programmes. As a result of this, 176 respondents said quality of living of elderly people is not satisfactory, 243 are of the opinion that they have low standard of living while 147 respondents said that the low quality of life has reduced their life span or longevity. Respondents also indicated that consequent upon lack of appropriate care by government while unemployment and inflation reduce the income of their children, elderly people according to them are exposed to different types of risks 179 sickness and early death, 144 hard labour problems, 98 hunger and diseases, 67 accidents at work or on farm, 56 negligence resulting in drug abuse, 43 sickness and early death, 41 frustration and sudden death, 21 overstressing and high blood pressure.

The study further found that elderly people are faced with different problems. The following problems were identified by the respondents, 446 no access to portable water, 68 no decent accommodation, 35 poor environment, 20 lack of care by children, 9 poor feeding. The factors are responsible for these problems as found in the study. 213 respondents said the problems are occasioned by improper planning by elderly people when they were young and government insensitivity (pensions not forthcoming regularly or not paid due to corrupt practices) , 146 negligence by the elderly people, 148 said no assistance by work place or community and children to earn good living, 118 were of the opinion that the fear elderly people associated with witchcraft often scare their children and relations from giving them necessary assistance while 29 respondents opined that government out rightly neglected elderly people in the scheme of things (welfare services).

\section{Discussion of Results}

The study examined the extent of care and support for the elderly people in four geo-political zones namely South-South, South-East, North-Central and South-West. Samples were drawn from a state each. The study showed that more men were aware of ageing people living in their environment than women. While the same trend was observed in SouthSouth, South-East and North-Central, women in the South-West were significantly better aware of elderly people living in their localities than men counterpart. Ordinarily, men are more likely by nature to interact better with the environment than women and besides their awareness are often better. However, because of the busy nature of Lagos men, rush to work and keeping ends meet in a competitive economy might be largely responsible for more women to be aware than men.

Apart from investigating knowing whether elderly people live in their area, the study further probed into whether respondents know with whom they live. The findings showed that elderly people live differently. Majority live with their children, some live with their extended family or relation, some live alone while few were said to live elsewhere (such as mission or old peoples home). There are some zonal differences in the pattern of elderly people live with. In South-South, elderly people live mostly alone while in South-East and South-West; they live mostly with their children whereas in North-Central, they live mostly with the extended family. This indicates cultural differences in pattern of living at elderly age. This agrees with National Population Policy (2004) which states that traditionally, the extended family system has cared for the Nigerian elderly which is also in consonance with findings by Okumagba (2011). Most elderly persons expect support from their relatives and friends, but most especially from their children. Thus, the need for the elderly age 
security was one of the motivations for large family size in the country. As a result of the declining economy, many children are not in position to provide care and support for their aged parents. Besides, the rising effects of HIVIAIDS epidemic which results in increasing mortality among working adults, implies that children are dying before their parents in some cases, leaving the elderly with reduced support and the additional responsibility of caring for orphans as the case is in states where the disease is most prevalent in Nigeria just as the case of Southern and Eastern Africa (Population Reference Bureau, 1999).

Just like young adults, elderly people engage in different occupation. Overall respondents indicated that a significant number of elderly people are self-employed, care for grand-children, as well as serving as nannies, sought employment with private individuals, and engage in politics and alms begging in streets and parks. This pattern of employment was also observed in each zone. Many are self-employed but the extent to which this can sustain a considerable number of them remains doubtful. The market places in the towns and villages are always full to the brim of traders of all assorted junks and consumables with the working capital of many of the wretched traders not more than 100 naira or less than one US dollar (Akinlosotu, 2004). In other words, due to poverty many elderly have little to invest in business. For most that engage in farming, such is at subsistence and can hardly sustain them.

Perhaps the most disturbing of the jobs they do is alms begging in streets and parks. According to Akinlosotu (2004) the aged move slowly to elaborate social parties where celebration of award of chieftaincy titles, final burial rites of grandparents, birthday, warming of new houses take place, uninvited and milling around guests begging for food and money or packing food ruminants' for consumption. The practice is common both in urban and rural areas in the country. It indicates highest point of lack of care and support for the elderly.

Majority of the respondents indicated that there is no welfare programme put in place for the elderly people. The same trend was reported in all the zones sampled. No social security, health scheme, food, financial security as well as viable policy choices that support elderly people. Where food is provided in some local government areas by government, such was a panic ally and politically motivated to gain the support of the elderly for winning elections and no sooner such elections were over they were dumped except in Ekiti and few other states where social security for the elderly people are part of the cardinal programmes of the government being implemented and sustained. The 6 point statements stated in the National Population Policy (2004) in respect of the need for elderly people to receive greater attention have not been implemented. This is because the Nigerian government and political leaders according to Ajomale (2007) believe that the provision of care for the elderly is the responsibility of families and hence policy emphasis is more on children, young people and women. Government also reneged in implementing constitutional provisions for the elderly people in terms of sustainable and adequate shelter, sustainable and adequate food, elderly age care and pensions. However, researches (Apt 1995; Aboderin 2006) have shown that this assumption is wrong. Because the elderly are poor, their quality of feeding is poor and ability to procure treatment is difficult, hence they often resort to cheap treatment by quacks or selfmedication or no mediation, and eventually they are diseased and die cheaply. Unfortunately, in all cultures sampled, burials of elderly who were denied good care by government, children and relatives are marked with colourful family dresses, social parties, expensive entertainments and sharing of gifts. To illustrate how our culture value the dead elderly people, some obituary posters have captions as 'A life well spent' or 'A glorious exit' or Victory at last' or 'Celebration of life and time' are reflections of the quality of life the deceased enjoyed which in reality are not so.

In addition, due to lack of social security, responses of the respondents revealed that elderly people suffer neglect, some lack good and decent accommodation to live, engage in hard labour in order to keep ends meet. No recreational facilities, access to portable water, poor living environment and lack of care from children and relations due to diminishing economic power, urbanization and influence of western culture that have aided breaking down of traditional value system culminating in charge of attitudes to elderly.

\section{Conclusion and Recommendations}

In Nigeria, the National Policy on Population (2004) states that the elderly aged 65 and above constitute about 3.3 percent of the population, and this is likely to increase in future. The study found that all the zones sampled, the pattern of living of elderly people appear to be unique. They live alone, with children and relations as well as living in aged people home is alien to our culture apart from non-provision of such. Poverty characterizes the living condition of most elderly people coupled with inadequate support and care from children relations and government. Consequently, elderly people engage in various types of jobs to eke living. Some of these activities are associated with fatigue, exposure to elderly, diseases and other devastating conditions. Thus, elderly people face a number of challenges and this is more so that there is virtually no viable policy addressing the welfare of elderly people. In view of these challenges, the paper recommends that existing population policy be reviewed to comprehensively address issues relating to elderly people 
welfare. The national assembly should sponsor and approve legislation mandating governments at all tiers to implement social security and welfare programmes for the elderly people. Such programme should include payment of elderly people allowances monthly, provision of free medical services, accommodation, food, and recreational facilities. Furthermore, in order to ensuring better quality of living for elderly people, government and political leaders need to evolve strategies that will promote the role of families and other informal support providers and participation of elders in local institutions for self-help, mutual assistance and outreach to others in their communities. Also, there is need to encourage civil society, Non-Governmental Organizations (NGOs), Faith-Based Organizations (FBOs) to create or increase welfare programmes for the aged in the society. In the same vein, the re-evaluation of cultural traditions to preserve beneficial practices and eliminate harmful ones need be encouraged.

\section{References}

Aboderin, I. (2006). Intergenerational support and elderly age in Africa., New Jersey: New Brunswick, Transaction.

Ajomale, O. (2007). Country report: Ageing in Nigeria - Current State, Social and Economic Implications. Summer News letter of the Research Committee (RC11) on the Sociology of Ageing of the International Sociological Association (ISA). Oxford Institute of Ageing, pp, 15-20.

Apt, N. (1995). Coping with Elderly Age in a Changing Africa. Aldershot: Avebury.

Brubaker, T.H\& Powers. E.A.(1976). The stereotype of "elderly". A review and alternative approach. Journal of Gerontology. 31(4),441-7. Federal Republic of Nigeria (2011). Amended Constitution of the Federal Republic of Nigeria. Abuja. Pp 32.

Federal Government of Nigeria (2004). National Policy on Population for Sustainable Development. Abuja: National Population Commission.

Federal Republic of Nigeria (2006). Population Census of the Federal Republic of Nigeria: Preliminary Report. Abuja: National Population Commission

Freund, A.M; Smith, J. (1997). Self-definition in elderly age. (German, abstract). Zeitschrift fur Sozialpsychologie, 28(1-2),44:59.

Gesinde, A.M; Adekeye, O.A. \& Iruonagbe, T.C. (2011). Counselling Services for Remediating the Biopsychosocial Challenges of the Aged in Nigeria. Journal of Functional Management. 3 (1) 89-98.

Glascock AP, Feinman S.L. (1980). A holocultural analysis of elderly age. Comparative Social Research, 3:311-32.

HelpAge International. Ageing Issues in Africa : A summary. www.helpage.org

Johnson. M.(1976). Is 65+ elderly? Social Policy. (Nov/Dec):9-12

Link Age (2000). Policy implications of global ageing. http://library.advanced.org/10120/cyber/extended/polity.html.

Mudiare, P.E.U.(2013). Abuse of the Aged in Nigeria: Elders Also cry. American International Journal of Contemporary Research, 3(9), 79-87.

Okoye, U.O. (2003). The erosion of traditional forms of care for the elderly and its implication for the elderly in Nigeria . Journal of Department of Social Work, University of Nigeria, Nsukk, Nigeria

Okumagba, O.P. (2011). Family Support for the Elderly in Delta State of Nigeria. Stud Home Comm Sci, 5(1), 21-27.

Population Reference Bureau (1999). Conveying concerns: women Report on Families in Transition. Retrieved from http://www.prb.org/pdf/familiesconveyingfinal.pdf

Sammut, J. (2007). Medicare is becoming a luxury we cannot afford it. Retrieved from http;//www.smh.com.an/news/opinion/medicinebecoming-a-luxury-we-cannot afford/2007/10/31..

Togunu-Bickersteth F.(1987) Chronological definitions and expectations of elderly age among young adults in Nigeria. Journal of Aging Studies, 1(2),113-24.

Togunu-Bickersteth F.(1988) Perception of elderly age among Yoruba aged. Journal of Comparative Family Studies, 19(1),113-23.

UNFPA (1999). Population Issues briefing kit. Retrieved from http://www.unfpa.org/6billion/ccmc/empowermentofwomen.html

UNFPA (1999). State of world Population. Retrieved from http://www.unfpa.org/public/cache/offence/home United Nations Population Division (2005)

US Bureau of Census (1999). Wikipedia the free Encyclopedia (2014). Demographics of Nigeria. En.wikipedia/wiki/Demographics....(Accessed 2/5/2014)

Wisensale, S.K. (2000). World population ageing and the generational equity issues in developed and developing nations. Paper presented at the $53^{\text {rd }}$ annual scientific meeting of the Gerontological Society of America, Washington, DC. 